\title{
DIÁRIOS E INVENTÁRIOS COMO PROCESSOS FORMATIVOS EM DANÇA
}

\section{NEILA CRISTINA BALDI}

Universidade Federal de Santa Maria

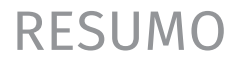

O presente texto discute o uso de diários de bordo e de inventários pessoais na formação do(a) artistadocente de dança. A partir dos relatos de estudantes de cursos de graduação em Dança, o artigo mostra as narrativas produzidas por estes e como estas são (auto) formativas. Para isso, o texto apresenta os conceitos de artistadocente e corpografias. Posteriormente, discorre sobre o uso de diários de bordo e de inventários pessoais. A presente discussão tem como principais aportes teóricos Fortuna (2012), Wegner (2011), Dominicé (2010) e Josso (2004). A partir da perspectiva de que criamos corpografias, o texto mostra como o trabalho com essas narrativas releva processos formativos e como a escrita das mesmas proporciona a construção do conhecimento como experiência e a formação de um(a) artistadocente reflexivo(a).

Palavras-chave: Dança. Autobiografia. Diário. Inventário pessoal.

\section{ABSTRACT}

\section{LOGBOOKS AND INVENTORIES AS TRAINING}

\section{PROCESSES IN DANCE}

This academic paper aims to discuss the use of logbooks and personal inventories in the formation of the dance artist. From the reports of undergraduate students in Dance, the article shows the narratives produced by them and how they are (self) formative. For this, the text presents the concepts of teachingartist and bodygraphies. Subsequently, it discusses the use of logbooks and personal inventories. The present discussion has as main theoretical contributions Fortuna (2012), Wegner (2011), Dominicé (2010) e Josso (2004). From the perspective of creating bodygraphies, the text shows how the work with these narratives emphasizes formative processes and how the writing of them provides the construction of knowledge as experience and the formation of a reflective artist.

Keywords: Dance. Autobiography. Logbook. Personal inventory. 


\section{RESUMEN DIARIOS E INVENTARIOS COMO PROCESOS FORMATIVOS EN DANZA}

El presente texto académico discute el uso de diarios de a bordo y de inventarios personales en la formación del artista de danza. A partir de los relatos de estudiantes de cursos de graduación en Danza, el artículo muestra las narrativas producidas por éstos y cómo éstas son (auto) formativas. Para ello, el texto presenta los conceptos de artista y cuerpografias. Posteriormente, discurre sobre sobre el uso de diarios de a bordo y de inventarios personales. La presente discusión tiene como principales aportes teóricos Fortuna (2012), Wegner (2011), Dominicé (2010) e Josso (2004). A partir de la perspectiva de que criamos cuerpografias, el texto muestra como el trabajo con esas narrativas relevan procesos formativos y cómo la escritura de las mismas proporciona la construcción del conocimiento como experiencia y la formación de un (a) artista reflexivo(a).

Palabras clave: Danza. Autobiografia. Diario. Inventario personal.

A formação do(a) artistadocente ${ }^{1}$ de dança dáse nos mais diferentes espaços-tempos, não se circunscrevendo apenas à formação universitária - até porque, nosso processo formativo é sempre um continuum. $\mathrm{O}(\mathrm{A})$ futuro artistadocente constrói modelos e formas de agir em todas as suas etapas formativas - desde o ensino não formal, em escolas de dança, no seu fazer em companhias de dança ou na graduação em Dança - Licenciatura ou Bacharelado. Em diversos destes espaços-tempos formativos, há o uso do diário de bordo - também denominado, por algumas pessoas, como diário de campo. A escrita de si, os inventários pessoais - que narram histórias de vida e suas relações com a dança, a arte e o movimento - também são comuns em processos criativos - aqueles que se utilizam da autobiografia para a concepção da obra artística. Ou seja, são dois instrumentos utilizados na dança, em alguns espaços-tempos formativos.

Mas como esses instrumentos podem ser

$1 \quad$ O termo será explicado no subitem: Espaços-tempos formativos do(a) artistadocente de Dança. usados em processos formativos de artistasdocentes em graduações de Dança? Qual a potencialidade dos diários e dos inventários pessoais? 0 presente texto discute o uso dos diários de bordo e dos inventários pessoais em cursos de Licenciatura em Dança, ou seja, nos processos formativos de futuros(as) artistasdocentes. Os relatos aqui discutidos foram levantados no período de 2013 a 2017, em dois cursos de graduação em Dança - um na Bahia, onde lecionei; outro no Rio Grande do Sul, onde agora atuo - com estudantes de segundo ao quinto semestre - a depender do componente curricular. Foram escritos em disciplinas eminentemente práticas - como Técnicas Corporais e Estágio de Criação - bem como teórico -práticas, como Práticas Educativas, Didática da Dança e Metodologia do Ensino da Dança. Em algumas ocasiões, a mesma turma esteve comigo em mais de um semestre, em outro componente curricular. Portanto, são cinco turmas, que variavam de cinco a 14 alunos(as), na faixa-etária por volta dos 20 anos - com uma ou outra pessoa mais velha. As escritas 
dos(as) estudantes foram analisadas, principalmente, a partir de Fortuna (2012), Wegner (2011), Dominicé (2010) e Josso (2004).

Para abordar a referida discussão, o texto conceitua os termos artistadocente e corpografias - para melhor entendimento da abordagem aqui apresentada - bem como expõe sobre o uso de diários de bordo e inventários pessoais na área da dança e, mais especificamente, na graduação. Por fim, aponta como estudantes de graduação de Dança enxergam(se) (n)esses instrumentos (como) formativos, bem como discute descobertas escritas nesses instrumentos.

\section{Espaços-tempos formativos do(a) artistadocente de Dança}

$O(A)$ artista da dança forma-se em diferentes espaços-tempos. Sua trajetória formativa dáse tanto em espaços formais quanto não-formais. Dá-se, inclusive, no seu fazer artístico. $O$ (A) professor(a) de dança também se forma nos mais diversos lugares. Em comum, nos dois casos, a formação não está circunscrita a um espaço-tempo ou ao ensino formal. Assim como acontece com o(a) professor(a) - de qualquer área - o(a) artista da dança ou professor(a) de dança tem contato com sua profissão muito antes de sua formação profissional.

Durante muito tempo - até a emergência das faculdades de dança, e mesmo com elas, esta prática ainda se dá - o(a) professor(a) de dança ou o artista da dança formava-se nos anos de estudos dedicados a esta arte, em uma analogia de mestre para discípulo. Ou seja, a partir, principalmente, do ensino não-formal, das escolas de dança. Isso significa que ele(a) aprendia o seu ofício fazendo-o: aprendia a dançar dançando e, depois de muito tempo dançando, virava bailarino(a) ou professor(a). No caso da docência, algumas vezes dava-se ao fim da carreira como artista.
Neste tipo de formação havia, na maior parte das vezes, lacunas. $O(A)$ bailarino(a), por exemplo, aprendia a ser intérprete, mas poucas vezes se aventurava a ser também criador(a) e, assim, um(a) artista no sentido de produtor(a) de arte. Por outro lado, no caso do(a) professor(a), a lacuna dava-se no sentido pedagógico. A pessoa tinha o conhecimento técnico da dança - havia aprendido uma dança específica, como ballet, jazz etc. e sabia como executá-la - mas raramente tinha noção de como ensinar. Segundo Marques e Brazil (2014), esse tipo de formação provocava a reprodução da pedagogia da cópia, do laissez-faire, da técnica vazia, uma vez que este profissional acabava por copiar o modo de fazer do(a) seu(sua) professor(a).

A emergência dos cursos de graduação em Dança - no Brasil, a partir de 1956, com a Universidade Federal da Bahia (UFBA) - pode ajudar a começar a preencher estas lacunas. São diversos os cursos que, em seus projetos pedagógicos, se propõem a formar um(a) artistadocente. Sobre esta questão, Wosniak (2017, p. 5) afirma que:

Artista e professor não são profissões antagônicas, mas também não são sinônimas, embora, uma não negue a outra. Os cursos de graduação em dança no país têm adotado a perspectiva da complementaridade, ou seja, uma habilitação complementa a outra.

Mas o que diferencia um(a) artistadocente de um(a) professor(a) de dança? Strazzacappa (2012, p. 65) diz que o(a) professor de dança não precisa ser artista fora da sala de aula:

[...] precisa ter sensibilidade para a dança. Ter visto dança, sentido dança, exercitado a criação em dança. O professor não precisa vivenciar a dança profissionalmente, mas precisa dançar para compreender seus conteúdos, sua importância e a sua expressão. (STRAZZACAPPA, 2012, p. 65)

Ou seja, não precisa ser a priori, um(a) bailarino(a) profissional, mas tem que ter vi- 
venciado a dança, dançado. Morandi (2010) também coaduna com a ideia de Strazzacappa (2012), lembrando que o conhecimento pedagógico é importante, mas há a necessidade de aprofundamento das especificidades da linguagem da dança, pela prática. Não é possível que eu ensine dança sem saber dançar, mas também não é necessário que eu seja uma bailarina excepcional para ser professora de dança. Mas aqui as duas autoras estão falando do(a) professor(a). E o (a) artistadocente?

Icle (2012, p. 18) diz que o professor-artista (termo utilizado por ele) não precisa produzir fora da escola (ou fora do espaço formativo), mas onde atua como artistadocente. “Lá, na escola, com os alunos, ele precisa ser artista, assumir o processo criativo que the permitirá fazer de seus alunos, alunos-artistas". Diz ele:

O professor-artista não seria uma soma de professor mais artista. Ele seria $100 \%$ artista e $100 \%$ professor. Não se trata de uma volta à tradição de se aprender arte com um artista. Mas longe de assumir o papel distanciado de quem acompanha o trabalho de seus alunos, ele próprio, deveria produzir, criar no espaço da escola o seu espaço de criação, desenvolver o seu processo poético e fazer participar os estudantes dessa escola. (ICLE, 2012, p. 17-18)

Pensamento semelhante tem Marques (2014, p. 235-236), que chama este(a) profissional de artista/docente:

[...] o artista/docente, tal qual proponho, não se configura como um professor que dança, ou que mantém uma carreira artística paralela às suas atividades docentes. 0 artista/docente é, tampouco, um artista que ensina nas horas vagas de seu trabalho artístico. [...] o artista/docente constitui-se no hibridismo, assim como a dança e a educação. 0 artista/docente é aquele que, numa mesma proposta, dança e educa: educa dançando e dança educando, consciente das duas ações fundidas que exerce.
A partir do exposto, considero que o hífen que separa as duas palavras não faz sentido. Seria, portanto, artistadocente ou professorartista. Como estamos falando em arte e não em qualquer processo pedagógico, considero ainda que o melhor termo seja artistadocente - a arte à frente da docência.

Antes de avançar, mais uma vez recorro a Icle (2012, p. 12), para outra ressalva: "a dimensão pedagógica é inerente à arte e, com efeito, não existe processo criativo que não contenha em si uma dimensão pedagógica". Desta forma, temos então artistasdocentes em processos artisticospedagógicos. A partir dessas premissas, a construção de um espetáculo de dança - em uma companhia, dentro da escola ou a partir de um curso livre - é um processo artisticopedagógico de dança.

Também é importante ressaltar que nossos processos formativos são um continuum. Estamos sempre nos formando, nos mais diversos espaços-tempos. Portanto, todos os processos artisticospedagógicos pelos quais passamos, ao longo de nossas vidas, são processos formativos no nosso vir a ser (ou não) artistasdocentes. Diversas pesquisas na área da educação mostram que os(as) alunos(as) tendem a repetir (e ou se inspirar em) procedimentos de seus professores e professoras. Na área da dança, autoras como Fortin (1998) e Woodruff (1999) também relatam que os processos formativos em dança influenciam os modos de proceder daqueles(as) que os vivenciaram. É lógico que ao longo de nossa existência passamos por diversos processos artisticospedagógicos e filtramos aquilo que gostamos ou não, aquilo com o qual nos identificamos ou não. Mas estes processos irão ajudar a tecer nossas corpografias. E, no caso dos(as) licenciandos(as) em Dança, aparecerão em seus inventários pessoais, em seus diários de bordo, em seus modos de dançar, ensinar dança etc. 


\section{Corpografias}

Em alguns campos e áreas do conhecimento - como a Educação Somática, a Sociologia, a Antropologia, a Psicologia, a Autobiografia, a Dança entre outros - há o entendimento de que temos inscrições - marcas do vivenciado assim como escrevemos na gente e nos outros - produzimos marcas. Zanella (2011, p. 9) diz que os acontecimentos que "[...] tocam cada sujeito, vão sendo registrados corporalmente, encaminhando toda uma maneira de assimilar, sentir e interagir com o mundo a sua volta." Ou seja, o que vivemos nos toca - nos inscreve e também acaba por ajudar a produzir outras marcas - escrever.

Jacques (2008) chama de Corpografias Urbanas uma cartografia realizada pelo e no corpo, a memória urbana inscrita no corpo, o registro da sua experiência da cidade. Ou seja, as inscrições. Mas não apenas temos marcas, também as produzimos. Por isso, refiro-me a corpografias como as escritas e inscritas corporais como um todo, às memórias corporais - no entendimento de que o corpo não é só a constituição física, mas o eu-sujeito.

E como estas corpografias podem emergir? Ou como tomamos consciência delas? De acordo com Staccioli (2005, p. 58 apud FORTUNA, 2012, p. 182):

[...] Como se sabe, a autobiografia refere-se às várias formas de escrita de si e a grafia é tudo isso que deixa um traço, um signo. Assim, de acordo com Staccioli, as histórias de vida podem ser 'traçadas com a pena ou a palavra, através de expressão corpórea, da música, da dança, do jogo, das imagens', sendo que 'os signos traçados podem ser encorpados ou etéreos, bidimensionais ou tridimensionais, duradouros ou fugazes'.

Ou seja, ao dançarmos, podemos também acessar nossas corpografias. E, no caso dos processos formativos em dança, elas são inúmeras, inclusive os modos de pensar-fazer dança, de ensinar, de criar etc. Uma vez que, como lembra Oliveira (2011, p. 125-126): nas narrativas - e aqui eu me refiro ao movimento dançado - "[...] percebemos os deslocamentos de sentidos numa trajetória pessoal e profissional, bem como os movimentos identificatórios". Portanto, as corpografias de licenciados(as) em Dança podem emergir tanto no movimento dançado quando na escrita - de diários de bordo, inventários pessoais etc.

\section{Diários e inventários pessoais na dança}

$\mathrm{Na}$ dança, os diários de bordo são cadernos, blocos de anotações que, na maioria das vezes, acompanham processos criativos. São chamados, em alguns casos, de diários de campo. Ou seja, são registros de processos criativos quando a pessoa está em período de montagem de espetáculos. Estes registros são comuns em companhias de dança contemporânea que se utilizam de processos colaborativos, ou seja, em que a criação da coreografia não nasce apenas do(a) diretor(a) ou coreógrafo(a), mas também dos(as) intérpretes que, neste caso, são chamados(as) também de intérpretes-criadores(as) ou criadores(as)-intérpretes. Os diários, nestes casos, servem para que o(a) intérprete-criador(a), a partir de suas anotações, aprofunde as questões do processo de criação da cena.

No entanto, os diários não são tão comuns como registros de aula - no ensino não-formal. Nas escolas de dança, não é uma prática fazer anotações em diários sobre o processo de ensino-aprendizagem. Mas estes registros têm sido utilizados em algumas práticas corporais ligadas à Educação Somática ou em aulas práticas de cursos de graduação em Dança. Nestes casos, na maioria das vezes, servem para que o(a) professor(a) tenha acesso às subjetividades do(a) aluno(a) no processo de construção 
do conhecimento de uma técnica de dança específica ou de um processo de criação. Poucas são as vezes em que o diário é pensando também para o(a) aluno(a) como parte do seu processo formativo. E, nestas ocasiões:

[...] essas anotações são um exercício de si de duplo uso, identicamente aos hypomnémata de que fala Foucault: uso para si mesmo, como forma de assimilação e retenção do que foi vivido em cada encontro, e uso pelo outro - no caso, pela pesquisa e por seus possiveis leitores -[...]. (FORTURNA, 2012, p. 188, grifo da autora)

Ou seja, servem para o(a) aluno, que não apenas registra, mas compreende seu processo de aprendizagem, ao mesmo tempo em que serve para o(a) professor(a) entender o processo pelo qual o(a) aluno(a) constrói o seu conhecimento em dança, expressa-o, bem como acessar questões subjetivas que concernem a este processo.

$\mathrm{Na}$ prática da dança - em processos artisticospedagógicos - assim como na prática docente em geral, muitas vezes realizamos ações sem parar para pensar nelas antes. "Neste tipo de situação, o conhecimento não precede a ação, mas, sim, está na ação" (CONTRERAS, 2012, p. 119). Mas, por outro lado, muitas vezes, pensamos sobre o que fazemos enquanto estamos fazendo, a chamada reflexão na ação. Ora, os diários podem servir como instrumentos para esta reflexão na ação. $\mathrm{E}$ mais que isso, para esta reflexão na ação na formação do artistadocente e durante a sua prática artisticopedagógica. Aqui, portanto, há outro uso do diário:

A escrita dos diários autobiográficos envolve o processo de contar a história de sua própria vida. Uma das diferenças entre teorização normal, ou cotidiana, do professor e a escrita sobre suas próprias experiências, pensamentos e sentimentos, é que esta última demora muito mais tempo. Há mais tempo para observar e refletir sobre o que se escolhe para ser contado. (HOLLY, 1995, p. 101 apud OLIVEIRA, 2013, p. 231)
Proponho o uso dos diários tanto em disciplinas predominantemente práticas, voltadas para as técnicas corporais, quanto também para as teórico-práticas, como as relativas à didática, metodologia e prática educativa em dança, ocasiões em que os(as) alunos(as) iniciam suas incursões na docência. Os diários dos(as) meus(minhas) alunos(as) são cadernos de anotações sobre as aulas, em que relatam percepções, dúvidas, sensações sobre o processo. A ideia não é registrar as aulas, os exercícios propostos, mas sobre como está sendo o processo. Neste sentido, o diário pode ser escrito imediatamente ao final da aula, mas também se pode escreverdançando - enquanto dança, registra o que ocorre, o que the move, o que sente etc. Ou até mesmo depois da aula, quando algo lhe faz rememorar a vivência da aula. Ou seja, o diário pode ser escrito durante, ao fim das aulas ou depois. Neste sentido, o diário de bordo:

[...] é capaz de capturar e expressar o processo formativo. É uma narrativa múltipla, de natureza biográfica, situada nas relações entre o aprender e o viver, que dá acesso não somente aos conhecimentos de seu autor, mas, principalmente, aos significados a eles atribuídos e às suas circunstancias, permitindo compreender o modo como esses significados se constroem e interferem na reconfiguração da sua identidade. (SÁ-CHAVES, 2005 apud FORTUNA, 2012, p. 187)

Nas minhas aulas - de componentes curriculares estritamente práticos ou teórico-práticos - o diário pode ser entregue em caderno, em folhas avulsas, nas mais diversas formas criativas - como dentro de um envelope - entre outras. Não há uma regra, um modelo. Fotografias do processo, desenhos, imagens diversas são bem-vindas. Cunha (2012, p. 210) diz que "a forma como vamos narrar uma pesquisa determinará o que ela é." Ou seja, a forma é conteúdo. E aqui o processo formativo pode ser entendido também como uma pesquisa, pesquisa sobre ser/estar sendo artistadocente. 
Outro instrumento comum na dança - sobretudo em processos criativos que se utilizam da autobiografia - são os inventários pessoais. Os inventários são escritas de si, nas quais a pessoa escreve sobre sua vida, desde o nascimento até os dias atuais, elencando fatos marcantes e escolhas do período. Na criação em dança, desses inventários podem emergir temas de espetáculos, temas de movimento etc.

Tenho trabalhado com este instrumento a partir das perguntas: como eu me tornei o que eu sou? Como estou sendo o que eu sou? Os(As) alunos(as) são convidados(as) a falar de si, não apenas a respeito de suas escolhas pela dança, mas da vida, de modo geral. Não é uma biografia educativa no sentido stricto. Mas pode ser considerada, às vezes, uma biografia educativa sobre dança. Para ajudá-los(as), a depender da turma, levanto questões: como foi/é a relação com o meu corpo? Quando criança, gostava de quê? Brincava de quê? Que tipos de movimentos buscava? Como encontrei a dança? O que dancei ao longo de minha vida? Estas questões podem ser levantadas antes da escrita da primeira versão do inventário, ou durante uma vivência rememorativa de suas vidas - prática que costumo realizar para ajudá-los(as) a escrever o inventário - ou após a escrita da primeira versão - depende da turma e do semestre. Mas o importante é que, ao longo de um semestre letivo, os inventários são reescritos. Para Wegner (2011, p. 33):

Esse conhecer a si, para o professor, é uma busca por compreender que as vivências que tivemos deixaram marcas positivas e/ou negativas, nos tornando o que somos hoje. É um caminhar em busca de saber quais imagens e representações nos formaram o professor que somos, as quais se revelam através de nossos sonhos, princípios, valores, sentidos dados aos fatos.

Considero que esta escrita é importante não só para o(a) professor(a), mas também para o(a) artista e, no caso específico dos(as) meus(minhas) licenciandos(as) em Dança, para o(a) artistadocente. Isto porque a escrita do inventário traz à tona memórias que formaram concepções sobre ensino, sobre dança, sobre docência, sobre criação em dança etc. Memórias estas que se corporificam em movimentos, em escolhas estéticas enquanto dançam. Desta forma, o inventário, para mim, é uma via de mão dupla: um modo de conhecer mais sobre minhas alunas e alunos e deles(as) identificarem características suas que se refletem em seus movimentos, em suas escolhas - estéticas, profissionais, entre outras - refletirem sobre suas vivências, num processo autoformativo.

Neste sentido, o uso de instrumentos do campo da Autobiografia acaba por ser tanto um método de pesquisa, mas também pedagógico. De acordo com Souza (2006), a Autobiografia evidencia e aprofunda aspectos das experiências educativas e da formação dos sujeitos, valorizando as experiências pessoais e profissionais, de modo que propicia o conhecimento de si e elucida os significados que os sujeitos conferem às suas vidas. No meu caso, nos diversos componentes curriculares com os quais costumo trabalhar, ocorrem estes dois vieses.

\section{Corpografias que emergem dos diários e inventários}

De acordo com Josso (2004, p. 40):

Falar de recordações-referências é falar, de imediato, que elas são simbólicas do que o autor compreende como elementos constitutivos da sua formação. A recordação-referência significa, ao mesmo tempo, uma dimensão concreta ou visivel, que apela para as nossas percepções ou para as imagens sociais, e uma dimensão invisivel, que apela para as emoções, sentimentos, sentidos ou valores. A recordação -referência pode ser qualificada de experiência formadora, porque o que foi aprendido (saber- 
fazer e conhecimentos) serve, daí para a frente, quer de referência a numerosíssimas situações do gênero, quer de acontecimento existencial único e decisivo na simbólica orientadora de uma vida.

Os inventários pessoais trazem, inevitavelmente, recordações-referências. Os relatos de minhas alunas e alunos de graduação em Dança, trazem à luz questões ligadas às suas relações como alunos(as), como artistas e, em relação à docência, mostram como foram seus processos formativos e como estas marcas, por vezes, podem ser negativas. É o caso de Isadora, ${ }^{2}$ aluna do 5o semestre da licenciatura em Dança, que escreveu em seu inventário, sobre sua infância: "Sentia-me rejeitada e apanhava das coleguinhas que se consideravam melhores". Seu relato vai ao encontro do que Dominicé (2010b, p. 147) fala a respeito das biografias educativas, de que elas permitem “[...] ao adulto tomar consciência das contribuições fornecidas por um ensino e, sobretudo, das regulações e autorregulações que dele resultam para o seu processo de formação". Na escrita, ela relata outros episódios de bullying, inclusive alguns vivenciados na graduação em Dança e, em determinado momento, escreve: "Talvez por isso gostasse mais de sentar nos cantos da sala, pois parecia estar mais protegida". Ela acrescenta uma reflexão que vai direto ao encontro entre o vivido na infância e seu comportamento em sala de aula, inclusive na graduação: "Pensando nisso, acredito que possa ter alguma relação com o fato de não gostar de ficar na frente nas aulas de dança, fico atrás, ao lado". Seu relato e sua reflexão sobre o vivido são de extrema importância, pois, como diz Shapiro (1998, p. 36, grifo da autora):

Por meio do processo crítico de refletir sobre experiências vividas, os estudantes são capacitados a interpretar as relações sociais e indivi-

2 Todos os nomes são fictícios, baseados em grandes personalidades da dança, no mundo e no Brasil. duais que vivem, e podem começar a entender seu próprio poder de transformar e recriar essas relações e, consequentemente, seu próprio mundo.

Isso significa que a escrita (ou a reflexão sem escrita) possa fazer com que a pessoa perceba a situação e a transforme. No caso específico desta aluna, além das colocações sobre bullying, elencadas em seu inventário pessoal, ela escreveu, diversas vezes, em seu diário, sobre seus medos - e os relacionou à sua história de vida. Ao longo do semestre, ela era convidada a sair do lugar "cristalizado" - nas aulas práticas faço revezamento do lugar na sala de aula e, além disso, realizei alguns trabalhos corporais que buscavam a superação do medo, para ajudá-la. Aqui não há uma relação do(a) professor(a) com psicólogo, mas, sim, como um(a) profissional atento(a) ao contexto, e que está disposto(a) a ajudar seus(suas) alunos(as) em seus processos formativos. Mudar de lugar espacialmente, em uma sala de aula de dança, é extremamente formativo, pois os espaços costumam se cristalizar. Alter (1986 apud STINSON, 1995) diz que há uma hierarquia velada nas aulas de técnicas codificadas, em que alguns alunos ou alunas, veteranos(as) ou mais ágeis, se colocam à frente dos demais, tendo prioridade na escolha espacial.

Ao final do semestre, solicitei aos(às) estudantes que escrevessem uma carta a alguém (amigo, parente etc.), em que apresentariam seu diário de bordo. Isadora escreveu o seguinte:

Nesta disciplina nós construímos um diário de bordo, que consiste em escrever em um caderno as experiências vivenciadas em aula, as atividades realizadas, as percepções, as dificuldades [...]. Espaço livre, nele eu colocava imagens, desenhava, conseguia expor o que dia-a-dia ia aprendendo. E como aprendi! Além de escrever, era muito bom reler da professora o retorno, as observações dela me confortavam a buscar melhorar. 
Importante aqui ela trazer a questão do feedback do(a) professor(a): o quanto nós devemos estar atentos às escritas dos(as) nossos(as) alunos(as). Não nos formamos sozinhos(as), vivemos em sociedade e por mais autoformativa que possa ser a escrita de si, o olhar do(a) outro(a) - professor(a), colega ou outra pessoa - também nos ajuda neste processo autorreflexivo.

Nos inventários pessoais, os(as) alunos(as) elencaram questões-problema (recordações -referências) ao longo de suas vidas e como estas têm influenciado suas ações, como no relato a seguir, de Martha, quando estava no quarto semestre:

Ao refletir sobre a minha infância, penso que foi o momento de minha vida que me deixou muitas marcas. Não sei exatamente quando foi que comecei a me machucar e passei a me dar conta disso, criando medos que antes não existiam. Na adolescência, houve um tempo em que meus colegas de escola me chamavam de boneca de porcelana, de tão frágil que me apresentava. Quando criança, tinha pouco cálcio nos ossos e isso esclarece a facilidade de quebrá-los. 0 medo de me machucar fisicamente passou a ser também um medo de me ferir emocionalmente. Acredito que a partir do momento que passei a ter consciência desta insegurança, comecei aos poucos a me forçar a fazer algo que considero arriscado. Aprendi que a vida muda num piscar de olhos. Tudo depende de nossas escolhas, decisões, machucados, a cada momento crescemos, experimentamos e aprendemos algo novo, e isso faz parte do nosso processo de encontrar quem somos nós. Hoje posso ser isso, amanhã sou isso e mais algo.

Ela reconheceu uma corpografia e, encarando-a, decidiu como contorná-la e escrever outras grafias. Sobre esta questão, Peres (2011, p. 73) afirma que: “Na medida em que o sujeito se pensa, muitos aspectos do vivido podem vir a tona para contribuir com o processo de formação posterior".
O modo como encaramos nossos medos e nossas marcas, varia conforme a pessoa. Ana, de outra turma, escreveu que, ao longo de sua infância, se machucou diversas vezes - sempre que estava "à procura de desafios". Segundo ela, a possibilidade de que isso se repita faz com que acabe se "[...] sentindo limitada e paralisada diante do meu medo". Suas corpografias restringem-na.

Apesar de trabalhar com autobiografia há alguns anos, tenho consciência de que escrever sobre si nem sempre é uma tarefa fácil. Muitas vezes, os(as) estudantes não querem entregar seus inventários pessoais ou não querem nem escrevê-los Se eu proponho, por exemplo, que troquem entre eles(as), para que a leitura do(a) colega o(a) ajude no preenchimento da lacuna das memórias, sempre há os(as) que não desejam fazê-lo. Pina, quando estava no quarto semestre - a primeira vez que nos encontramos no curso de Licenciatura em Dança - escreveu em seu inventário: "Falar do meu passado é uma tarefa bem dificil para mim, rememoro momentos que não gostaria de lembrar". De acordo com Lani-Bayle (2012), as tomadas de consciência podem ser desestabilizadoras e podem suscitar resistências à narrativa, mesmo quando o motivo não aparece de forma clara. Por isso, na avaliação dele, devemos ter claro até onde a autobiografia pode (ou não) ir. É um processo, por vezes, dolorido, mas que não pode ser entendido como terapia. É preciso compreender que:

\section{[...] carregamos nossas corpografias, que se ma- nifestam no nosso movimento, no nosso fazer dança, no nosso fazer docente e que identifi- cando-as podemos decidir se queremos con- tinuar ou não com elas. E que nem sempre a identificamos ou nem sempre identificamos no momento de reflexão. (BALDI, 2017, p. 287)}

Por sua vez, Maya escreveu em seu inventário pessoal que: "Trazer à mente minhas lembranças é instigante e provocador. Minha in- 
fância é uma lacuna em minha memória". Ela acrescenta, em seu texto que: "Relembrar tudo isso deixa a minha estrutura abalada, sinto isso no meu corpo". Ou seja, segundo ela, essa lembrança a afeta fisicamente.

Se os inventários pessoais trazem questões gerais sobre os seus processos formativos, os diários de bordo traziam apontamentos específicos de descobertas do componente curricular trabalhado - técnica corporal, prática educativa ou outro, a depender do semestre e da turma - mas também percepções dos(as) alunos(as) sobre a docência e a discência e seus respectivos papéis. Sobre este tema, é interessante a colocação de Agripina que questiona, em seu diário, quando, por exemplo, uma sequência é demonstrada no centro da sala e ela, de onde está, não consegue ver. Aqui é clara uma visão tradicional de ensino e de aluno(a). Ela se coloca em um lugar físico (e também imaginário) do qual parece que não pode sair. Como dito anteriormente, é comum, nas aulas práticas de dança, a "cristalização dos lugares" e, para que isso não ocorra, proponho sempre que troquemos o lugar a cada sequência, no caso das aulas eminentemente práticas.

Em outro momento do diário, Agripina acrescentou: "Fico em dúvida se estou certa ou se ela quer que me autocorrija. Quando estou fazendo, gosto que digam, que falem que é assim ou assim". Mais uma vez há uma concepção de ensino subjacente à escrita dela - o(a) professor(a) é o(a) único(a) responsável pelo conhecimento, é ele(a) quem deveria "corrigi -la". É muito comum, em aulas de dança, este tipo de pensamento. De acordo com Salosaari (2001), alunos e alunas se acostumam a seguir o que o(a) professor(a) propõe e frequentemente perguntam como o professor ou professora quer que ele(a) - aluno(a) - faça.

Especificamente sobre a docência, em um diário de Técnicas Corporais, Isadora escreveu: "A vivência desta disciplina me ensinou que, por mais dificil que possa parecer, é possivel auxiliar seu educando a desenvolver a criatividade e a vencer as dificuldades". Ela já tinha uma graduação, também na área da educação - era a mais velha de sua turma -, mas foi no seu processo, com suas dificuldades, que teve consciência disso. E acrescentou ainda, no seu diário, que: "conhecer o discente, suas limitações e anseios é necessário para o desenvolvimento do trabalho e para que as relações interpessoais aconteçam e levem ao crescimento mútuo".

Da mesma turma, também no quinto semestre, Margô escreveu que as aulas de balé clássico na faculdade iriam ajudá-la no seu fazer docente a: “[...] pensar melhor na colocação do corpo e nos passos dos meus alunos, dando a possibilidade de criarem e experimentarem seus corpos, não sendo totalmente marionetes, mas bailarinos autônomos". Ou seja, o modo como ela vivenciou uma técnica de dança a fez repensar sobre a docência em dança e em como ela poderia atuar.

Rudolf, de turma diferente, também apontou, em seus diários, como a sua atividade, como discente, em uma disciplina de prática da dança, ajudou-o a pensar na sua docência:

Às vezes parar pra pensar em como ressignificar um código é um pouco estranho, não há muito o que fazer ou como fazer. Mas acabei descobrindo a partir das aulas de criação que existem maneiras de fazer isso, usando o tempo, espaço, ritmo, direção espacial etc. Me fez repensar o modo de ver e de ensinar.

Josso (2004, p. 241) diz que: “aprender não é apenas aprender isto ou aquilo; é descobrir novos meios de pensar e de fazer diferente; é partir à procura do que poderá ser este 'diferente"'.

Mesmo quando o diário traz questões que parecem muito específicas sobre o componente curricular, estas podem ser pensadas para além dele. Maria escreveu o seguinte relato: 
[...] vivenciamos os movimentos com os olhos fechados, depois os mesmos movimentos com os olhos abertos, com apoio da parede, sem apoio da parede. Observamos também os colegas para entendermos os nossos movimentos. Notamos uma diferença muito grande de realizar com os olhos fechados porque perdemos a noção de espaço, é outra codificação feita pelo cérebro.

Ela descreveu exatamente um modo de repetição de sequências coreográficas e como este modo pode ser considerado uma repetição diferenciada e suas implicações para a aprendizagem. Isto porque, do ponto de vista neuromotor, quando memorizado, o movimento deixa de ser voluntário - quando preciso planejar a sua execução - para ser automático - quando já está coordenado de tal forma que não preciso mais ter de planejar a sua execução antes de fazê-lo. Esses movimentos automáticos - armazenados na chamada memória não declarativa - vão compor um banco de repertório motor, que pode ser acessado em determinadas situações (SCHACK, 2010). Neste sentido, Bellini (2015, p. 93) afirma que: "diante de situações que envolvam a aprendizagem e a memória, nosso cérebro opera mudanças nas redes neurais reorganizando as células nervosas em função dos processos desenvolvidos pelos circuitos cerebrais".

Em uma das reflexões produzidas ao longo do semestre, Mary escreve que: "Entender os conceitos trabalhados e colocá-los em movimento de uma sequência já pronta tem se tornado fácil para mim. 0 desafio e a dificuldade é em criar os movimentos". Aqui temos duas questões: muitas vezes os(as) alunos(as) de dança, ao longo de sua formação, não são estimulados a criar, mas a reproduzir criações coreográficas de outras pessoas e ela estava sendo desafiada a isso. Outra questão é a da formação do artistadocente ou professor(a) de dança. Se eu penso na perspectiva de artistadocente, tenho então de proporcionar aos(às) estudantes momentos de criação de movimentos, de células coreográficas etc., ou seja, momentos em que também desenvolvam o lado de artistas criadores(as) até porque, mesmo na docência, também estarão criando.

Outro apontamento de um diário, específico dos saberes da dança, mas que pressupõe entendimentos e (pré)conceitos a respeitos de dança e técnica é a seguinte colocação, de Yvone: "Acredito que o nosso aprendizado nas aulas, além de nos ter aprimorado na técnica, tem servido para ampliar o nosso repertório em dança". Há, nas entrelinhas, um entendimento de técnica como algo "engessador" e, de repente, o modo como a técnica é trabalha$\mathrm{da}$, the permite visualizar novos movimentose, com isso, ampliar o seu repertório.

Os diários também trazem indicações que têm relações com suas biografias educativas. Trisha escreveu o seguinte relato:

Acho legal a forma como o balé tem sido trabalhado em nossas aulas. Tem muita diferença de quando eu fazia balé. Dessa maneira podemos compreender de forma mais ampla como executar os movimentos, além de ajudar aqueles que nunca tiveram contato com a dança clássica.

Ela consegue ver que o seu processo formativo, dentro da graduação em Dança, é bem diferente do realizado anteriormente, em uma escola de dança - ensino não-formal. Do mesmo modo que consegue perceber o quanto o conhecimento construído dançando a ajudará no ensino de dança. Esta mesma aluna, ao final do quinto semestre, escreveu uma carta à sua ex-professora - a carta em que apresentaria o diário de bordo. Nesta escrita, colocou o seguinte:

Não te julgo por ser tão tradicional, porque infelizmente você veio dessa cultura, mas convido você a pesquisar, buscar coisas novas para suas aulas, tenho feito isso nas minhas aulas em Apuarema e tá dando certo, minhas alunas amam. 
0 relato dela vai ao encontro de outros, no sentido de que a prática de dança, vivenciada na graduação, afetava o seu fazer docente. Maria, aluna do componente curricular Técnicas Corporais escreveu em seu diário: "São novas formas de se fazer/pensar os movimentos do balé. E isso vem me afetando, em todas as práticas: artísticas e pedagógicas". Por sua vez, sua colega Tatiana, que nunca havia vivenciado a técnica do balé clássico anteriormente, também viu, no que estava vivenciado no curso, possibilidades futuras e fez relações com o passado:

Após mais de 10 aulas, percebo que é possivel aprender uma dança/técnica. Diferente dos cursos que dizem que, para aprender balé, é preciso começar na infância. Enquanto licencianda em dança, percebo também uma metodologia eficaz para ser trabalhada nas possiveis aulas de dança e estágios. Metodologia essa que alcança todos, não apenas alguns. Sobretudo quem já conhece.

As percepções de ambas vão ao encontro do pensamento de Josso (2004) sobre uma experiência formadora. Segundo a autora:

[...] o que faz uma experiência formadora é uma aprendizagem que articula, hierarquicamente: saber-fazer e conhecimentos, funcionalidade e significação, técnicas e valores num espaçotempo que oferece a cada um a oportunidade de uma presença para si e para a situação, por meio da mobilização de uma pluralidade de registros. (JOSSO, 2004, p. 39)

Encerro esta discussão sobre o uso dos diários e inventários em processos formativos de dança com o relato de Cecília, uma das poucas alunas mais velhas da turma, quando estava no quinto semestre: "Com o passar das aulas e das atividades, descobria que minhas inquietações eram também de minhas colegas". Aqui ela traz uma colocação que mostra o quanto há singularidade e pluralidade nos processos autobiográficos, pois:
[...] todas as narrações autobiográficas relatam, segundo um corte horizontal ou vertical, uma práxis humana. [...] Toda a vida humana se revela, até nos seus aspectos menos generalizáveis, como a síntese vertical de uma historia social. (FERRAROTTI, 2010, p. 44)

Considero que para ela, como aluna, é importante perceber que não está sozinha em suas inquietações, para que não ache que é a pessoa que tem mais dificuldades. $E$, durante $o$ processo, estimulo que percebam que não estão sós. Para isso, uma das estratégias é a troca de diários e/ou inventários. Compartilhamento este que traz outras implicações, como a destacada por Josso (2004, p. 67):

É quase sempre destacado, no momento em que as pessoas partilham a sua experiência vivida, que o trabalho da escrita levou-lhes a realizar modificações importantes da sua narrativa oral a fim de integrarem aí as experiências rememoradas ao ouvirem outras narrativas ou porque a emergência de elos entre as experiências narradas reativou outras recordações.

\section{Considerações finais}

Como afirma Pereira (2013, p. 21): “[...] não é pelo simples fato de passar por um curso de formação (seja uma licenciatura, seja magistério) que alguém vem a ser professor". Na avaliação dele, "vir a ser professor é uma diferença de si que o sujeito produz culturalmente (no campo coletivo), num dos inumeráveis movimentos de constituição no mundo" (PEREIRA, 2013, p. 22). Ou seja, a formação é contínua e não se dá só nos espaços formais e a esta constituição ele chama de professoralidade. A partir desta perspectiva, estamos todos(as) nos formando, o tempo todo, nos mais diferentes espaçostempos. Assim, os relatos dos(as) alunos(as) apontam quanto a escrita de si - em forma de diários ou inventários pessoais - é formativa. Ela ajuda a nos formar porque nos dá consciência do que vivemos, do que estamos viven- 
do, do que desejamos viver e de como pretendemos, pois, como afirma Dominicé (2010a, p. 95): a "formação depende do que cada um faz do que os outros quiseram, ou não quiseram, fazer dele."

Neste sentido, as memórias dos(as) alunos(as) de licenciatura em Dança apresentam seus caminhos (auto)formativos, suas concepções de professor(a), de ensino, de dança. Pois, como nos lembra Tardif (2016), a profissão docente é uma das poucas em que temos contato durante muitos anos de nossa vida, formando concepções sobre a mesma.

Os exercícios de memória dos(as) estudantes mostram que seus relatos são singulares e plurais. Singulares porque partem da individualidade, mas plurais porque, como afirma Larrosa (2006, p. 25), "toda escritura pessoal, enquanto escritura, contém vestígios das palavras e histórias recebidas". Além disso, são plurais porque podem ser replicados. O conhecimento reflexivo construído por um(a) pode ser o mesmo de outro(a). A descoberta a partir da sua vivência pode ajudar a resolver problemas semelhantes em outras situações, e assim sucessivamente. Ou, como atesta Wegner (2011, p. 30):

[...] refletir sobre a experiência pode auxiliar no processo de conhecimento de si com vistas a ajudar em outras situações; saber como se aprende e o que foi formador, de forma a interferir nesse processo de construção (interminável) do ser, adaptando determinado aprendizado a outros momentos semelhantes.

São experiências singulares e plurais porque aprendemos em comunhão com o(a) outro(a), porque não escrevemos por escrever, escrevemos "[...] porque tínhamos algo a contar da vida, porque tínhamos uma experiência a compartilhar [...]" (OLIVEIRA, 2013, p. 234).

Por sua vez, o uso de instrumentos autobiográficos permite outros tipos de conhecimento, que não só o autoformativo, uma vez que:
Trabalhar com o autobiográfico consiste em habitar os conteúdos, dar-lhes vida, vinculá-los com a experiência e a realidade. $E$, neste ponto, podemos voltar à metáfora do professor como DJ, já que a música que ele ou ela escolheram é um corpo de conhecimento reconhecido por sua audiência e possivelmente amado, mas mais que isso, é um conhecimento que se torna experiência, a experiência de dançar. (ACASO, 2013, p. 152)

Entendo, então, que a formação que se utiliza de processos autobiográficos permite que esta aprendizagem seja uma experiência - aquela no sentido de Larossa (2002), do que de fato nos toca, nos afeta. Entendo também que esse tipo de formação permite que ajudemos a formar artistasdocentes reflexivos, cuja formação se refletirá para além dela, uma vez que:

Um profissional que refleta-na-ação tende a questionar a definição de sua tarefa, as teorias-na-ação das quais ela parte e as medidas de cumprimento pelas quais é controlado. $E$, ao questionar essas coisas, também questiona elementos da estrutura do conhecimento organizacional na qual estão inseridas suas funções. (SCHÖN, 1983, p. 383-9 apud CONTRERAS, 2012, p. 122)

Artistasdocentes reflexivos que refletem na ação não somente enquanto escrevem suas memórias, mas no próprio fazer a dança, como escreveu Pina: “Vejo a importância de os alunos estarem o tempo todo refletindo sobre as possibilidades de movimento". Isto porque, nas aulas práticas, eram convidados(as), o tempo todo, a pensar o mesmo movimento de mais de uma forma, com mais de uma iniciação. Acredito que, assim, com processos formativos que passam por processos autobiográficos, estou formando artistasdocentes que poderão atuar na escola formal ou não formal e que poderão mudar os modos como a dança vem ensinando, e criar novas formas de produção e ensino. 


\section{Referências}

ACASO, María. Reduvolution: hacer la revolución en la educación. Barcelona: Paidós, 2013.

BALDI, Neila Cristina. Por um balé somático: Cartas sobre o aprenderensinar balé clássico por meio das abordagens de Béziers e Laban/Bartenieff e do Construtivismo Pós-Piagetiano. 2017. 340 f. Tese (Doutorado em Artes Cênicas) - Programa de PósGraduação em Artes Cênicas, Universidade Federal da Bahia, Salvador, 2017.

BELLINI, Magda. O papel das imagens internas: a cegueira como potência cognitiva. In: KATZ, Helena; GREINER, Christine. (Org.). Arte e cognição: corpomídia, comunicação, política. São Paulo: Annablume, 2015. p. 77-110.

CONTRERAS, José. A autonomia de professores. 2. ed. São Paulo: Cortez, 2012.

CUNHA, Jorge Luiz da. Pesquisas com (auto)biografias: interfaces em tempos de individuação. In: PASSEGI, Maria da Conceição; ABRAHÃO, Maria Helena Menna Barreto. (Orgs.). Dimensões epistemológicas e metodológicas da pesquisa (auto)biográfica. Tomo I. Natal: EDUFRN; Porto Alegre: EDIPUCRS; Salvador: EDUNEB, 2012. p. 95-114.

DOMINICÉ, Pierre. O processo de formação e alguns dos seus componentes relacionais. In: FINGER, Mathias; NÓVOA, António. 0 método (auto)biográfico e a formação. São Paulo: Paulus; Natal: EDUFRN, 2010a. p. 81-96.

A biografia educativa: instrumento de investigação para a educação de adultos. In: FINGER, Mathias. NÓVOA, Antonio. 0 método (auto) biográfico e a formação. São Paulo: Paulus; Natal: EDUFRN, 2010b. p. 143-154.

FERRAROTTI, Franco. Sobre a autonomia do método biográfico. In: FINGER, Mathias; NÓVOA, António. (Orgs.). 0 método (auto)biográfico e a formação. São Paulo: Paulus; Natal: EDUFRN, 2010. p. 21-58.

FORTIN, Sylvie. Quando a ciência da dança e a educação somática entram na aula técnica de dança. Pro-posições, Campinas, Unicamp, v. 9, n. 2 (26), p. 79-95, junho de 1998.
FORTUNA, Tânia Ramos. Ludobiografia: uma invenção metodológica em pesquisa (auto)biográfica em educação. In: PASSEGI, Maria da Conceição; ABRAHÃO, Maria Helena Menna Barreto. (Orgs.). Dimensões epistemológicas e metodológicas da pesquisa (auto)biográfica. Tomo II. Natal: EDUFRN; Porto Alegre: EDIPUCRS; Salvador: EDUNEB, 2012. p. 165-202,

ICLE, Gilberto O que é pedagogia da Arte? In: ICLE, Gilberto. Pedagogia da arte: entre-lugares da escola - volume 2. Porto alegre: Editora da UFRGS, 2012. p. 11-22.

JACQUES, Paola Berenstein. Corpografias urbanas. Arquitextos, ano 8, fev. 2008. Disponivel em: <http:// www.vitruvius.com.br/revistas/read/arquitextos/08.093/165>. Acesso em: 19 fev. 2017.

JOSSO, Marie-Christine. Experiências de vida e formação. São Paulo: Cortez, 2004.

LANI-BAYLE, Martine. Narrativas de vida: motivos, limites e perspectivas. In: PASSEGI, Maria da Conceição; ABRAHÃO, Maria Helena Menna Barreto. (Orgs.). Dimensões epistemológicas e metodológicas da pesquisa (auto)biográfica. Tomo II. Natal: EDUFRN; Porto Alegre: EDIPUCRS; Salvador: EDUNEB, 2012. p. 59-78

LARROSA, Jorge. Pedagogia profana: danças, piruetas e mascaradas. 4. ed. Belo Horizonte: Autêntica, 2006.

. Notas sobre a experiência e o saber de experiência. Rev. Bras. Educ., n. 19, p. 20-28, 2002.

MARQUES, Isabel. O artista/docente: ou o que a arte pode aprender com a educação. Ouvirouver, Uberlândia v. 10, n. 2, p. 230-239, jul./dez. 2014.

MARQUES, Isabel; BRAZIL, Fábio. Arte em questões. São Paulo: Cortez, 2014.

MORANDI, Carla. A dança no ensino da arte. In: STRAZZACAPPA, Márcia; MORANDI, Carla. (Org.). Entre a arte e a docência: a formação do artista da dança. Campinas, SP: Papirus, 2010. p. 29-38.

OLIVEIRA, Marilda Oliveira de. O que pode um diário de aula? In: MARTINS, Raimundo; TOURINHO, Irene. (Orgs.). Processos e práticas de pesquisa em Cul- 
tura Visual e Educação. Santa Maria: Editora UFSM, 2013. p. 225-236.

OLIVEIRA, Valeska Fortes. A escrita como dispositivo na formação de professores. In: PERES, Lúcia Maria Vaz; ZANELLA, Andrisa Kemel. (Orgs.). Escritas de autobiografias educativas: o que dizemos e o que elas nos dizem? Curitiba: CRV, 2011. p. 123-135.

PEREIRA, Marcos Villela. Estética da professoralidade: um estudo crítico sobre a formação do professor. Santa Maria: Editora UFSM, 2013.

PERES, Lúcia Maria Vaz. No vai e vem da vida a escrita como um processo de (auto)formação. In: PERES, Lúcia Maria Vaz; ZANELLA, Andrisa Kemel. (Orgs.). Escritas de autobiografias educativas: 0 que dizemos e o que elas nos dizem? Curitiba: CRV, 2011. p. 65-78.

SALOSAARI, Paula. Multiple embodiment in classical ballet. Educating the Dancer as an Agent of Change in the Cultural Evolution of Ballet. 2001. 149 f. Tese (Doutorado em Artes Cênicas) - Theatre Academy, Yliopistopaino, Helsinki, 2001.

SCHACK, Tomas. Building blocks and architecture of dance. In: BLÄSING, Betina; PUTTKE, Martin; SCHACK, Tomas. (Orgs.) The neurocognition of dance: mind, movement and motor skills. New York: Psychology Press, 2010. p. 11-40.

SHAPIRO, Sherry B. Em direção a professores transformadores: perspectivas feminista e crítica no ensino de dança. Pro-Posições, Campinas, v. 9, n. 2 (26), p. 35-53, jun. 1998.

SOUZA, Elizeu Clementino de. A arte de contar e trocar experiências: reflexões teórico-metodológicas sobre história de vida em formação. Revista Educação em Questão, Natal, EDUFRN, v. 25, n. 11, p. 22-39, jan./abr. 2006.

STINSON, Susan. Uma pedagogia feminista para a dança da criança. Pro-posições, Campinas, v. 6, n. 3, p. 77-89, nov. 1995.

STRAZZACAPPA, Márcia. Dançando na chuva... e no chão de cimento. In: FERREIRA, Sueli. (Org.). 0 ensino das artes - construindo caminhos. Campinas, SP: Papirus, 2012. p. 39-87.

TARDIF, Maurice. Saberes docentes e formação profissional. 17. ed. Petrópolis, RJ: Vozes, 2016.

WEGNER, Bárbara Pires. Reelaboração de uma trajetória através da escrita de um diário. In: PERES, Lúcia Maria Vaz; ZANELLA, Andrissa Kemel. (Orgs.). Escritas de autobiografias educativas: 0 que dizemos e o que elas nos dizem? Curitiba: CRV, 2011. p. 12-34.

WOODRUFF, Dianne. Treinamento na dança: visões mecanicistas e holísticas. Cadernos do GIPE-CIT, Salvador, n. 2, p. 17-30, fev. 1999.

WOSNIAK, Cristiane. A universidade e a formação do artista-docente da(na)dança. Revista 0 Teatro Transcende, FURB, Blumenau, v. 22, n. 1, p. 3-18, 2017.

ZANELLA, Andrisa Kemel. Onde está a biografia do meu corpo? In: PERES, Lúcia Maria Vaz; ZANELLA, Andrisa Kemel. (Orgs.). Escritas de autobiografias educativas: o que dizemos e o que elas nos dizem? Curitiba: CRV, 2011. p. 9-26.

Recebido em: 31.01.2017 Aprovado em: 30.08 .2017

Neila Cristina Baldi é Doutora em Artes Cênicas - Universidade Federal da Bahia. Professora do Curso de Dança-Licenciatura - Universidade Federal de Santa Maria. Grupo de Pesquisa sobre (Es)(Ins)critas do/no corpo (Corpografias). e-mail: neila.baldi@ufsm.br

Universidade Federal de Santa Maria. Av. Roraima, 1000, prédio 51, Camobi - Santa Maria, RS CEP 97105-9000. Telefone: (55) 3220-8315 